\title{
STUDY OF SEROPREVALENCE AND SYNDROMIC VALIDATION OF HSV2 AMONG GENITO-ULCERATIVE DISEASE PATIENTS ATTENDING STI CLINIC IN A TERTIARY CARE HOSPITAL
}

\author{
Hina Rahagdale ${ }^{1}$, Supriya S. Tankhiwale 2 , R. B. Surpam ${ }^{3}$
}

${ }^{1}$ Senior Resident, Department of Microbiology, Government Medical College, Nagpur.

${ }^{2}$ Associate Professor, Department of Microbiology, Government Medical College, Nagpur.

3 Professor, Department of Microbiology, Government Medical College, Nagpur.

\section{ABSTRACT}

\section{BACKGROUND}

Role of genital ulcer diseases (GUD) in facilitating heterosexual transmission of HIV in developing countries is well established. Genital herpes infection is the primary cause of GUD worldwide. Variable reports are available worldwide, showing variation in different epidemiological markers in relation to HSV2 prevalence.

Aims and Objectives- To study the seroprevalence and syndromic validation by serum HSV2 IgM in GUD, and to study the epidemiological markers in herpes IgM positive patients.

\section{MATERIALS AND METHODS}

Ninety six GUD patients from April 2015 - May 2016 attending the STD clinic attached to a tertiary care hospital of central India were included in this study. After taking detailed history, Tzanck smears were prepared from ulcer scrapings to look for the presence of multinucleated giant cells (MNGC). $10 \mathrm{~mL}$ blood was collected for HSV2 IgM type specific antibodies by Ratio Diagnostics kit Germany according to the manufacturer's guidelines.

\section{RESULTS}

Out of 96 STI clinic attendees, clinically suspected cases of GUD-herpes were 71, out of which 35 (49.29\%) were laboratory confirmed. 34/71 patients (47.88\%) were Herpes IgM positive. Different epidemiological markers were studied in relation with HSV positive patients.

\section{CONCLUSION}

Syndromic management is useful in places where laboratory diagnostic facility is not available, but in doing so we are overdiagnosing and over-treating the patients which is a cause of concern especially in an era of drug resistance.

\section{KEYWORDS}

Seroprevalence, Herpes, Genitoulcerative Disease, Syndromic Validation.

HOW TO CITE THIS ARTICLE: Rahagdale H, Tankhiwale SS, Surpam RB. Study of seroprevalence and syndromic validation of HSV2 among genito-ulcerative disease patients attending STI clinic in a tertiary care hospital. J. Evolution Med. Dent. Sci. 2017;6(36):2984-2986, DOI: 10.14260/Jemds/2017/643

\section{BACKGROUND}

The role of sexually transmitted infection (STI), and Genital ulcer diseases (GUD) in particular, in facilitating heterosexual transmission of HIV in developing countries is well established. ${ }^{1}$

This recognition has led to increased focus on STI cases to be managed at the health care centres using syndromic approach. ${ }^{2}$ Numerous studies have identified the higher relative risk of HIV infection with GUD than with other STI and STI syndromes. ${ }^{1}$

Genital herpes infection is the primary cause of GUD worldwide. ${ }^{3}$ Despite increased awareness of herpes infection, herpes remains underdiagnosed because the majority of infection is asymptomatic. Symptomatic infection may

Financial or Other, Competing Interest: None.

Submission 30-03-2017, Peer Review 24-04-2017,

Acceptance 29-04-2017, Published 04-05-2017.

Corresponding Author:

Dr. Supriya S. Tankhiwale,

Associate Professor,

Dept. of Microbiology,

Government Medical College,

Nagpur - 440023

E-mail: supriyatankhiwale@yahoo.com

DOI: $10.14260 /$ jemds $/ 2017 / 643$

\section{(c) $(1) \ominus$}

present in unusual or atypical ways, increasing the diagnostic challenge. ${ }^{4}$

Until now the diagnosis of herpes infection has been based on typical clinical presentation without any laboratory confirmation. After infection with HSV, specific antibodies are formed against the pathogen which can be detected by various serological methods. Because it is possible to differentiate between the individual classes of immunoglobulins by enzyme immunoassay, more precise statement about the status of patients can be made with these tests, than other tests like the Haemagglutination Inhibition assay or Complement fixation test. ${ }^{5}$

Variable reports are available worldwide, showing variation in sex, occupation, and educational status in relation to HSV2 prevalence. Hence, the present study was undertaken for knowing the seroprevalence of HSV2 in all GUD cases, its syndromic validation and its relation with some epidemiological markers in STI patients in a tertiary care centre.

\section{MATERIALS AND METHODS}

96 GUD patients from April 2015 to May 2016 attending STD clinic attached to a tertiary care centre of central India were included in this study. 
After taking consent, and clearance from Institutional Ethical committee detailed clinical history especially regarding the age, occupation, education, high risk behaviour like multiple partner were recorded. For Tzanck smear, the bottom of the ulcer was scraped with scalpel or curette; smear was prepared on a clean grease free microscope glass slide and allowed it to dry in air. Finally, it was stained with Giemsa stain. 6

Ten mL blood without anticoagulant was collected aseptically from each GUD patient. Sera was separated and tested for HSV2 IgM type specific antibodies by Ratio Diagnostics kit Germany, and Ratio ELISA Herpes simplex virus 2 IgM ELISA was done according to the manufacturer's guidelines.

\section{RESULTS}

Out of the 96 STI clinic attendees, $72(75 \%)$ were male \& $24(25 \%)$ female patients. In this study all patients were above 15 yrs., majority of the patients belonged to age group between 26 - 45 yrs. followed by $46-55$ yrs. (Table-1).

\begin{tabular}{|c|c|c|c|c|c|c|}
\hline \multirow[b]{2}{*}{ Age Group } & \multicolumn{3}{|c|}{ Male } & \multicolumn{3}{|c|}{ Female } \\
\hline & $\begin{array}{l}\text { HSV IgM } \\
\text { Negative }\end{array}$ & $\begin{array}{l}\text { HSV IgM } \\
\text { Positive }\end{array}$ & $\begin{array}{c}\text { Tzanck } \\
\text { Smear Positive }\end{array}$ & $\begin{array}{l}\text { HSV IgM } \\
\text { Negative }\end{array}$ & $\begin{array}{l}\text { HSV IgM } \\
\text { Positive }\end{array}$ & $\begin{array}{c}\text { Tzanck } \\
\text { Smear Positive }\end{array}$ \\
\hline $15-25$ yrs. & 7 & 6 & 0 & 7 & 2 & 1 \\
\hline $26-35$ yrs. & 14 & 9 & 0 & 4 & 3 & 0 \\
\hline 36- 45 yrs. & 10 & 8 & 3 & 4 & 2 & 0 \\
\hline 46- 55 yrs. & 7 & 3 & 0 & 2 & 0 & 0 \\
\hline$>55$ yrs. & 7 & 1 & 0 & 0 & 0 & 0 \\
\hline Total - 96 & 45 & 27 (79.4\%) & 3 & 17 & $7(20.58 \%)$ & 1 \\
\hline
\end{tabular}

Tzanck smear showed multinucleated giant cells seen in $4 / 71(5.63 \%)$ cases of clinically diagnosed GUD herpes (Figure-1). One of four Tzanck smear positive, tested negative by HSV2 IgM ELISA. Herpes IgM HSV2 antibody were detected in 34/71 (35.41\%) patients out of which 7 (20.58\%) were female and $27(79.41 \%)$ were male. Total HSV2 positive were 35/71(49.29\%). However, remaining 25 cases tested positive for other STI's. Two cases which were positive for HSV2 IgM were clinically diagnosed as non-herpetic GUD.

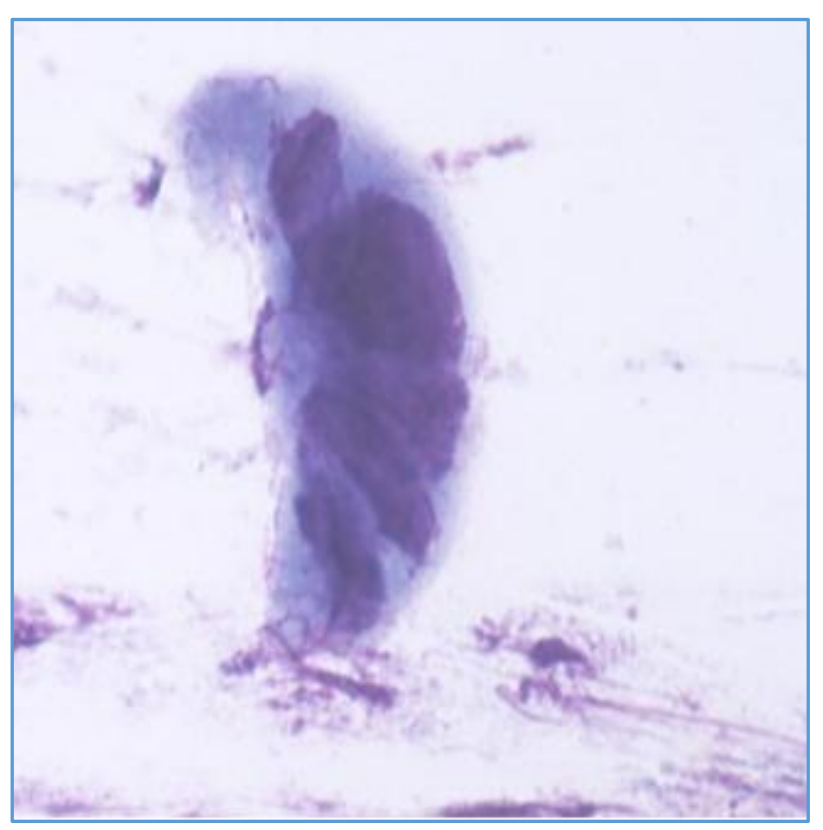

Figure 1. Showing Multinucleated Giant Cell in Tzanck Smear

Majority of HSV2 IgM positive patients belong to 26-45 yrs. age group (64.7\%) Only one male patient of 65 yrs. age was positive for HSV2 IgM (Table 1).

Out of 96 patients, $41(42.7 \%)$ had completed their matriculation/ graduation (Table -2). Occupation history suggested that majority of patient were migrant labourers (26/34-76.47\%). All female patients, except one daily wage labourers, were housewives. Husband of two, out of seven females were HSV2 positive (Table-3).

\begin{tabular}{|c|c|c|}
\hline Education & STI attendee & HSV2 +ve \\
\hline 0 -1 year & $4(4.16 \%)$ & $2(5.88 \%)$ \\
\hline Primary school & $7(7.2 \%)$ & $2(5.88 \%)$ \\
\hline Secondary school & $45(46 \%)$ & $19(55.88 \%)$ \\
\hline Matriculation & $22(22.91 \%)$ & $6(17.64 \%)$ \\
\hline Graduation & $19(19.79 \%)$ & $5(14 \%)$ \\
\hline Total & 96 & 34 \\
\hline
\end{tabular}

\begin{tabular}{|c|c|c|}
\hline Occupation & No. Tested & No. (\%) Positive \\
\hline Hawker & $13(13.5 \%)$ & $4(11.76 \%)$ \\
\hline Labourers & $25(26.04 \%)$ & $11(32.35 \%)$ \\
\hline Housewife & $24(25 \%)$ & $8(23.52 \%)$ \\
\hline Driver & $9(9.37 \%)$ & $3(8.82 \%)$ \\
\hline $\begin{array}{l}\text { Private job } \\
\text { (Salesman) }\end{array}$ & $24(25 \%)$ & $8(23.52 \%)$ \\
\hline Unemployed & $1(1 \%)$ & Nil \\
\hline Total & 96 & $34(35.41 \%)$ \\
\hline \multicolumn{3}{|c|}{ Table 3. Occupation Wise Distribution of Cases } \\
\hline
\end{tabular}

\section{DISCUSSION}

This study applies to the clinical presentation of STD \& serological correlation of STD clinic attendees in the tertiary care centre. In the present study, all the 96 patients presented in STI clinic with single or multiple genital ulcer(s). 71/96 (73.95\%) were clinically suspected as herpetic GUD.

There are number of commercial ELISA tests available for detecting type specific HSV infection. These tests are simple to perform, economical and easily available. The sensitivity varies depending on the antigen used in the test. IgM antibodies are usually detectable after 9 -10 days after exposure to virus and last for 7-10 days. Sometimes it may be detectable up to 6 weeks in certain individuals. ${ }^{7}$ Serological testing of all 96 patients by Capture ELISA for HSV2 IgM showed $34 / 96(35.41 \%)$ positive results. This result is 
comparable with result of Shilpee Choudhary et al from Delhi who reported prevalence of $30 \% .^{5}$

Steven J Reylonds from Pune reported HSV2 prevalence at $43 \%$ which is slightly higher than the present study. Other Indian studies like Dharmishta et al \& Poornima et al reported HSV2 prevalence of $11.36 \%$ \& $15.6 \%$ respectively from different places of India. ${ }^{8-10}$

Nigel 'O' Farell from Durban, South Africa reported 84.6\% HSV2 antibodies in patients of genital ulcer. ${ }^{11}$ Yusuf et al from Nigeria reported $87 \%$ prevalence of HSV2 in STI attendees. ${ }^{12}$ Wide variation in seroprevalence of HSV2 is seen in different places of world. Foreign study reported higher prevalence than Indian studies.

In the present study, higher prevalence is reported in men (35.41\%) than women $(20.58 \%)$ which was also observed by others. 12

An interesting finding is regarding the educational status, which is not having any effect on prevalence of HSV2 infection. In the present study, almost $43 \%$ patients have completed secondary education or graduation, and almost $50 \%$ cases have completed schooling from $7^{\text {th }}$ to $10^{\text {th }}$ grade. This observation was similar to Yusuf et al \& Weiss $\mathrm{H}$ et al. ${ }^{12,13}$

Most patients belong to the labourer class which is in contrast to the findings of Weiss et al that there was no significant effect on socioeconomic status on prevalence of HSV2 infection. ${ }^{13}$

There were 71 clinically suspected cases of GUD herpetic, but IgM antibody was found positive in 32 cases only. Out of 96 cases of GUD, two cases were IgM positive which were not clinically suspected of herpetic GUD. The syndromic validation was possible in $34 / 71$ cases $(47.8 \%)$. Out of 96 cases, 34 cases (35.41) tested serologically positive for herpes IgM antibody. Chetan Bhavsar et al reported 22.53\% (16/71) positive by IgM, $19.71 \%(14 / 71)$ by Tzanck smear and 3 by both the tests. 14 Thus, they were able to validate 33 $(46.47 \%)$ cases by laboratory test similar to present study. On the other hand, a foreign study by Gomes Novaca F was able to detect slightly higher percentage of HSV2 DNA in 55.35 cases, and that too by using a molecular technique (PCR test). ${ }^{15}$ So, syndromic validation of around $50 \%$ to $55 \%$ could be done when molecular technique was used. This means, syndromic diagnosis and treatment leads to over-diagnosing and treating the cases by drugs which may not be indicated.

\section{CONCLUSION}

To conclude we found $47.8 \%$ seroprevalence of Herpes in clinically diagnosed GUD-H patients. Educational status of patients has no effect on prevalence of HSV2. Labourers were found more affected than individuals from other occupation showing that socioeconomic status has an effect on seroprevalence of HSV2. Syndromic management is useful in places where laboratory diagnostic facility is not available, but by this we are over-diagnosing and over-treating the patients which is a cause of concern especially in an era of drug resistance.

\section{ACKNOWLEDGEMENTS}

The authors acknowledge National AIDS Control Organisation (NACO), New Delhi and Maharashtra State AIDS Control Society, Mumbai for financial support. We are thankful to Dr. R.P. Singh for sending the cases and Mrs. Kalindi Deogade, Mrs. Sonali Gosavi and Mrs. Manisha Sharma for their technical support.

\section{REFERENCES}

[1] O'Farrell N. Increasing prevalence of genital herpes in developing countries: implication for heterosexual HIV transmission and STI control programmes. Sex Transm Infect 1999;75(6):377-84.

[2] World Health Organization. Management of patients with sexually transmitted diseases. WHO technical report series No.810. Geneva World Health Organization; 1991.

[3] Paz-Bailey G, Ramaswamy M, Hawkes SJ, et al. Herpes simplex virus type 2: epidemiology and management options in developing countries. Sex Transm Infect 2007;83(1):16-22.

[4] Singh A, Preiksaitis J, Romanowski B, et al. The laboratory diagnosis of herpes simplex virus infections. Can J Infect Dis Med Microbiol 2005;16(2):92-8.

[5] Choudhry S, Ramachandran VG, Das S, et al. Serological profile of HSV-2 in patients attending STI clinic: evaluation of diagnostic utility of HSV-2 IgM detection. Indian J Pathol Microbiol 2009;52(3):353-6.

[6] National AIDS Control Organization. Standard operative procedures for laboratory investigations in diagnosis of STI/RTIs New Delhi: NACO ministry of health and family welfare, Government of India; 2013.

[7] Ho DW, Field PR, Irwing WL, et al. Detection of immunoglobulin $\mathrm{M}$ antibodies to glycoprotein $\mathrm{G}-2$ by western blot (ImmunoDOT) for diagnosis of initial herpes simplex virus type 2 genital infections. J Clin Microbiol 1993;31(12):3157-64.

[8] Reynolds SJ, Risbud AR, Shepherd ME, et al. Recent herpes simplex virus type 2 infection and the risk of human immunodeficiency virus type 1 acquisition in India. J Infect Dis 2003;187(10):1513-21.

[9] Tada DG, Khandelwal N. Serum HSV-1 and 2 IgM in sexually transmitted diseases more for screening less for diagnosis: an evaluation of clinical manifestation. J Glob Infect Dis 2012;4(3):S1-4.

[10] Madhivanan P, Krupp K, Chandrasekaran V, et al. The epidemiology of herpes simplex virus type-2 infection among married women in Mysore, India. Sex Transm Dis 2007;34(11):935-7.

[11] O'Farrell N, Morison L, Moodley P, et al. Genital ulcers and concomitant complaints in men attending a STI clinic: implications for STI management. Sex Transm Dis 2008;35(6):545-9.

[12] Agabi YA, Banwat EB, Mawak JD, et al. Seroprevalence of herpes simplex virus type-2 among patients attending the sexually transmitted infections clinic in Jos, Nigeria. J Infect Dev Ctries 2010;4(9):572-5.

[13] Weiss H. Epidemiology of herpes simplex virus type 2 infection in the developing world. Herpes 2004;11(Suppl 1):24A-35A.

[14] Bhavsar C, Patel RM, Marfatia Y. A study of 113 cases of genital ulcerative disease and urethral discharge syndrome with validation of syndromic management of sexually transmitted diseases. Indian J Sex Transm Dis 2014;35(1):35-9.

[15] Naveca FG, Sabido M, de Almeida TAP, et al. Etiology of genital ulcer disease in a sexually transmitted infection reference center in Manaus, Brazilian Amazon. PLoS One 2013;8(5):e63953. 